\title{
A Study On Role of Mass Media in Society
}

\author{
Kiran Walia \\ Assistant Professor, Bhutta College of Education, Ludhiana, India
}

\begin{abstract}
In the present paperentitled "A study on role of mass media in society", an attempt is made to explore and delineate the role and impact of media on society and in the construction of public belief and attitudes of peopleof district Ludhiana. It also discusses how government and media have complimentary roles in the task of nation building. A sample of 100 college teachers and college students has been taken from the professional colleges of district Ludhiana. The data is collected with the help of self-structured questionnaire. Results show the role of mass media and its impact on society.
\end{abstract}

Keywords: Role, Mass Media, Society, Impact, Public belief, Attitude.

\section{Introduction}

In today's world, mass media is as important as food and other things to lead a life. Modern media is quite helpful in strengthening a society. It is considered as "reflection" of the modern society. The purpose of the media is to keep people updated about happeningsand current affairsin the society. It is in charge of information, education, entertainment, advertisementetc. There was a time when man was not aware of the happenings of theworld; his outer knowledge was just up to his village or town. But as time passes, with the advancement in technology, new things invented and many new gadgets like Camera, Satellite, Microphone, Machinery etc. were invented. These gadgets made life easy for every individual living in the society. Man was being updated day by day and minute by minute from each and every news. Now in this time, media is so vast that one just need to turn on his television and he gets all the knowledge that he wants or even just by searching on search engines on the internet he gets each and every information regarding, news, geography, politics, history, music, entertainment and many more and for this thecommon example everyone has is google.com. People now can find each and everything by just writing the name on this search engine and they can see the information about that particular subject in the very next second.Thus it can be said that if there would be no media, then there would belife but without any knowledge and information.Media is an important tool which helps the people to make opinion and judgments about the issues of society. People stay informed due to very cautious media which keeps a check on society. But media also acts as a double edged sword as young generation easily gets attracted towards the bad things shown by media to get easy fame. Due to lack of proper knowledge they may make an opinion that whatever information given via media is true, which is not always right.

\section{Need of the Study}

No doubt that the media affects people's perspective. Buttoo much intervention of media in everything is a matter of concern. Media can be considered as "watch dog" in democratic countries like India. Through the ages, the emphasis of media on news has disguised. Media these days, tries to eye the news, which could help them to sell the information that is gathered worldwide, so that they could pave a way of success and fame of their respective channels.
Radios, newspapers, internet and television are the mass Medias that serve to reduce the communication gap between the audience, viewers and the media world. For the sake of publicity and selling, important people, their lifestyles are usually beleaguered. Irrelevant andunimportant news, that normally have no importance are given importance and due to a reason or the other,they get onto the minds of the viewers and in this way many a times,important social, political andeconomicnews get neglected and gradually, lose their importance. In this way the role of media has become one way of trading and marketing of products and prejudices. The media claimed to be governed by righteousness and equity, but greed and selfaggrandizementhas poisoned its virtues. Thus the present problem has been selected by the investigator to study the role played by media and its impact on society in present scenario.

\section{Objectives of the Study}

- To find out the most popular form of mass media.

- To study the role and impact of mass media on society.

\section{Methodology}

Survey method was adopted to conduct the study. College students and teachers were identified within the administrative boundary of Ludhiana district and they were interviewed as well as detailed information was sought with the help of a structured questionnaire.

\section{Sample}

The sample of the study comprised of college going students $(\mathrm{N}=50)$ and college teachers $(\mathrm{N}=50)$ of district Ludhiana making a total of 100 .

\section{Tool}

The tool used in the present study was a self-constructed questionnaire. Besides, a semi-structured interview schedule was also used to obtain data. The investigator herself collected the data from the selected sample.

\section{Analysis and Interpretation of the Data}

The study based on the data obtained from teachers and college students present the following demographic detail of the sample involved in the study. 


\section{International Journal of Science and Research (IJSR) \\ ISSN (Online): 2319-7064 \\ Index Copernicus Value (2013): 6.14 | Impact Factor (2014): 5.611}

Table 1: Showing demographic information of survey respondents

\begin{tabular}{|c|c|c|c|c|}
\hline \multicolumn{5}{|c|}{ Survey respondents' demographic information } \\
\hline Total Sample & Teachers & Students & $\begin{array}{c}\text { Age Range } \\
20 \text { s }\end{array}$ & $\begin{array}{c}\text { Age Range } \\
30 \mathrm{~s}\end{array}$ \\
\hline 100 & $50 \%$ & $50 \%$ & $63 \%$ & $37 \%$ \\
\hline
\end{tabular}

Table 2: Showing the popular form of media

\begin{tabular}{|c|c|c|c|c|}
\hline \multicolumn{5}{|c|}{ Popular Form of Media } \\
\hline Total sample & T.V & Radio & Internet & Newspaper \\
\hline Teachers (N=50) & $30 \%$ & $10 \%$ & $40 \%$ & $20 \%$ \\
\hline Students (N=50) & $35 \%$ & $5 \%$ & $50 \%$ & $10 \%$ \\
\hline
\end{tabular}

Table shows that $30 \%$ of teachers and $35 \%$ of students like to watch t.v. , $10 \%$ of teachers and $5 \%$ of students like radio, $40 \%$ of teachers and $50 \%$ of students like to surf on internet and only $20 \%$ of teachers and $10 \%$ of students like to read newspapers. Thus results show that internet is the most popular form of media amongst teachers and college going students.

Table 3: Showing the type of programmes they like to watch on T.V.

\begin{tabular}{|c|c|c|}
\hline Type of Programme & Teachers $(N=50)$ & Students $(N=50)$ \\
\hline Educational & $15 \%$ & $5 \%$ \\
\hline News & $20 \%$ & $5 \%$ \\
\hline Sports & $10 \%$ & $20 \%$ \\
\hline Entertainment & $55 \%$ & $70 \%$ \\
\hline
\end{tabular}

Table shows that $15 \%$ of teachers and $5 \%$ students like to watch educational programmes on TV.,20\% of teachers and $5 \%$ of students like watch news, $10 \%$ of teachers and $20 \%$ of students like to watch sports programmes and 55\% of teachers and $70 \%$ of students like to watch entertainment programmes. Thus results show that entertainment programmes are more popular amongst teachers and college going students.

Table 4: Showing the interest in Newspaper reading

\begin{tabular}{|c|c|c|}
\hline Type of response & Teachers & Students \\
\hline YES & $98 \%$ & $65 \%$ \\
\hline NO & $2 \%$ & $35 \%$ \\
\hline
\end{tabular}

$98 \%$ of the teachers and $65 \%$ of the students agreed with the statement whereas $2 \%$ of teachers and $35 \%$ of students disagreed with it.Thus, results show that newspaper is a popular form of media amongst teachers and college going students

Table 5: Showing what they like to read in a Newspaper.

\begin{tabular}{|c|c|c|}
\hline Type of Sections & Teachers $(N=50)$ & Students $(N=50)$ \\
\hline Educational & $5 \%$ & $4 \%$ \\
\hline News & $45 \%$ & $15 \%$ \\
\hline Sports & $20 \%$ & $24 \%$ \\
\hline Entertainment & $30 \%$ & $57 \%$ \\
\hline
\end{tabular}

Table shows that $5 \%$ of teachers and $4 \%$ students like to watch educational programmes on TV.,20\% of teachers and $15 \%$ of students like watch news, $20 \%$ of teachers and $24 \%$ of students like to watch sports programmesand $30 \%$ of teachers and $57 \%$ of students like to watch entertainment programmes. Thus, results show that entertainment programmes are more popular amongst teachers and college going students.
Table 7: Showing the response whether media has brought the world closer

\begin{tabular}{|c|c|c|}
\hline Type of response & Teachers $(N=50)$ & Students $(N=50)$ \\
\hline YES & $98 \%$ & $93 \%$ \\
\hline NO & $2 \%$ & $7 \%$ \\
\hline
\end{tabular}

$98 \%$ of the teachers and $93 \%$ of the students agreed with the statement whereas $2 \%$ of teachers and $7 \%$ of students disagreed with it. Thus, results show that both the teachers and the students believe that media has brought the world closer.

Table 8: Showing the response regarding the accuracyof information given by mass media

\begin{tabular}{|c|c|c|}
\hline Type of response & Teachers $(N=50)$ & Students $(N=50)$ \\
\hline YES & $77 \%$ & $88 \%$ \\
\hline NO & $33 \%$ & $12 \%$ \\
\hline
\end{tabular}

$77 \%$ of the teachers and $88 \%$ of the students agreed with the statement whereas $33 \%$ of teachers and $12 \%$ of students disagreed with it.Thus, results show thatboth the teachers and the students believe that information given by media is accurate.

Table 9: Showing the response whether media acts as a watch dog for Govt.

\begin{tabular}{|c|c|c|}
\hline Type of response & Teachers $(N=50)$ & Students $(N=50)$ \\
\hline YES & $67 \%$ & $85 \%$ \\
\hline NO & $33 \%$ & $15 \%$ \\
\hline
\end{tabular}

$67 \%$ of the teachers and $85 \%$ of the students agree with the statement whereas $33 \%$ of teachers and $15 \%$ of disagreed with it.Thus, results show thatboth the teachers and the students believe that media acts as a watch dog for Govt.

Table 10: Showing response whether media has become commercialized these days

\begin{tabular}{|c|c|c|}
\hline Type of response & Teachers $(N=50)$ & Students $(N=50)$ \\
\hline YES & $62 \%$ & $77 \%$ \\
\hline NO & $38 \%$ & $23 \%$ \\
\hline
\end{tabular}

$62 \%$ of the teachers and $77 \%$ of the students agree with the statement whereas $38 \%$ of teachers and $23 \%$ of students disagreed with it.Thus, results show thatboth the teachers and the students believe that media has become commercialized these days.

Table 11: Showing response whether entertainment has become the main component of mass media

\begin{tabular}{|c|c|c|}
\hline Type of response & Teachers $(N=50)$ & Students $(N=50)$ \\
\hline YES & $47 \%$ & $33 \%$ \\
\hline NO & $53 \%$ & $67 \%$ \\
\hline
\end{tabular}

$47 \%$ of the teachers and $33 \%$ of the students agreed with the statement whereas $53 \%$ of teachers and $67 \%$ of students disagreed with it.Thus, results show thatboth the teachers and the students believe thatentertainment has become the main component of mass media. 


\section{International Journal of Science and Research (IJSR) \\ ISSN (Online): 2319-7064 \\ Index Copernicus Value (2013): 6.14 | Impact Factor (2014): 5.611}

Table 12: Showing response whether mediapromotes trade and industry through advertisements

\begin{tabular}{|c|c|c|}
\hline Type of response & Teachers $(N=50)$ & Students $(N=50)$ \\
\hline YES & $90 \%$ & $98 \%$ \\
\hline NO & $10 \%$ & $2 \%$ \\
\hline
\end{tabular}

$90 \%$ of the teachers and $98 \%$ of the students agreed with the statement whereas $10 \%$ of teachers and $2 \%$ of students disagreed with it.Thus, results show thatboth the teachers and the students believe thatmedia promotes trade and industry through advertisements.

Table13: Showing response whether media promotes violence in the society

\begin{tabular}{|c|c|c|}
\hline Type of response & Teachers $(N=50)$ & Students $(N=50)$ \\
\hline YES & $68 \%$ & $95 \%$ \\
\hline NO & $32 \%$ & $5 \%$ \\
\hline
\end{tabular}

$68 \%$ of the teachers and $95 \%$ of the students agreed with the statement whereas $32 \%$ of teachers and $5 \%$ of students disagreed with it.Thus, results show thatmost of the teachers and the students believe that media promotes violence in the society.

Table 14: Showing response whether media gives negative effects on the society

\begin{tabular}{|c|c|c|}
\hline Type of response & Teachers $(N=50)$ & Students $(N=50)$ \\
\hline YES & $53 \%$ & $76 \%$ \\
\hline NO & $47 \%$ & $24 \%$ \\
\hline
\end{tabular}

$53 \%$ of the teachers and $76 \%$ of the students agreed with the statement whereas $47 \%$ of teachers and $24 \%$ of students disagreed with it.Thus, results show that most of the teachers and the students believe thatmedia gives negative effects on the society.

Table 15: Showing response whetherGovt. should take steps or make some laws to stop media portrayal of violence

\begin{tabular}{|c|c|c|}
\hline Type of response & Teachers $(N=50)$ & Students $(N=50)$ \\
\hline YES & $95 \%$ & $87 \%$ \\
\hline NO & $5 \%$ & $13 \%$ \\
\hline
\end{tabular}

$95 \%$ of the teachers and $87 \%$ of the students agree with the statement whereas $5 \%$ of teachers and $13 \%$ of students disagreed with it.Thus, results show that most of the teachers and the students believe thatgovt. should take steps or make some laws to stop media portrayal of violence.

Table 16: Showing the response of importance of role of media for a better society

\begin{tabular}{|c|c|c|}
\hline Type of response & Teachers $(N=50)$ & Students $(N=50)$ \\
\hline YES & $67 \%$ & $95 \%$ \\
\hline NO & $33 \%$ & $5 \%$ \\
\hline
\end{tabular}

$67 \%$ of the teachers and $95 \%$ of the students agree with the statement whereas $33 \%$ of teachers and $5 \%$ of students disagreed with it.Thus, results show that most of the teachers and the students believe that media is very important for a better society.
Table 17: Showing the impact of media on behavior and routine work

\begin{tabular}{|c|c|c|}
\hline Type of response & Teachers $(N=50)$ & Students $(N=50)$ \\
\hline YES & $88 \%$ & $77 \%$ \\
\hline NO & $12 \%$ & $33 \%$ \\
\hline
\end{tabular}

$88 \%$ of the teachers and $77 \%$ of the students agree with the statement whereas $12 \%$ of teachers and $33 \%$ of students disagreed with it.Thus, results show that most of the teachers and the students believe that media effects one's behavior and routine work also.

\section{Conclusion}

Thus from above analysis, it can be concluded that there is no doubt that media has acted significantly to bring the world closer. Significance of media cannot be ignored. However, unchecked commercialization of media has produced challenges for society in terms of biased and hot selling news, uncensored and easily available adult content. But I believe if media keeps a check on these loopholes and identify its responsibility towards society; it can do wonders in making a healthy, prosperous and educated nation.

\section{References}

[1] Duncan, B. (1988). Mass Media and Popular Culture. Toronto, Ont.: Harcourt, Brace \& Co. Canada.

[2] Hall, S. (1973). Encoding and decoding in the television discourse. Birmingham, England: Centre for Cultural Studies, University of Birmingham

[3] Philo, G. (1990). Seeing Is Believing. British Journalism Review, 1, 4, 58-64.

[4] Wanta, W., Golan, G., Lee C. (2004). Agenda Setting and International News: Media Influence on Public Perceptions of Foreign Nations. Journalism \& Mass Communication Quarterly. 